\title{
Borderline Ovarian Mucinous Tumor
}

National Cancer Institute

\section{Source}

National Cancer Institute. Borderline Ovarian Mucinous Tumor. NCI Thesaurus. Code C40036.

A low grade mucinous epithelial neoplasm arising from the ovary. It is characterized by an atypical proliferation of mucinous-type epithelial cells without evidence of stromal invasion. The mucinous epithelial cells may be of intestinal or endocervical type. 